\title{
Pengalaman Mempertahankan Komitmen Berpasangan pada Perempuan Dewasa Awal yang Menjalani Hubungan dengan Laki-Laki yang Memiliki Penyakit Kronis
}

IDA AYU GEDE KUSUMAASTUTI WIDIHAPSARI*, SYNTIA AGUNG LIANA PUSPITA, NI MADE DYAH SATHYA PRADNYADARI, DIAN RAKHMAWATI, I DEWA AYU MAYTHALIA JONI, \& WIWIN HENDRIANI

Program Studi Magister Psikologi Profesi, Fakultas Psikologi Universitas Airlangga

\begin{abstract}
ABSTRAK
Penelitian ini bertujuan untuk mengetahui pengalaman mempertahankan komitmen berpasangan pada perempuan dewasa awal yang menjalani hubungan dengan laki-laki yang memiliki penyakit kronis. Komitmen merupakan segala kekuatan baik positif maupun negatif yang berfungsi untuk mempertahankan individu dalam suatu hubungan. Orang yang merasa terikat pada suatu hubungan dengan orang lain akan senantiasa berada bersama-sama dengan orang itu dalam suka maupun duka. Penelitian ini menggunakan pendekatan kualitatif dengan tipe penelitian fenomenologi. Penelitian ini melibatkan satu orang partisipan perempuan dewasa awal berusia 31 tahun yang menjalani hubungan berpasangan selama 13 tahun dengan laki-laki yang memiliki penyakit kronis. Teknik penggalian data pada penelitian ini menggunakan wawancara dengan pertemuan sebanyak dua kali dengan partisipan. Teknik analisis yang digunakan adalah analisis interpretative phenomenological analysis (IPA). Hasil penelitian ini menunjukkan bahwa partisipan memiliki pandangan yang berbeda mengenai komitmen berpasangan. Selama menjalani hubugan berpasangan, partisipan juga menghadapi beragam tantangan yang memengaruhi komitmennya. Faktor-faktor yang memperkuat komitmen berpasangan yang didapatkan melalui penelitian ini juga bervariasi.
\end{abstract}

Kata kunci: komitmen berpasangan, perempuan dewasa awal, penyakit kronis

\begin{abstract}
This study aims to determine the experience of maintaining dating commitment in early adult women who had a relationship with men who had chronic diseases. Commitment is all positive and negative forces that function to maintain individuals in a relationship. People who feel bound to a relationship with others will always be with that person in both joy and sorrow. This study uses a qualitative approach to the type of phenomenology research. The study involved one 31-year-old female adult participant who had a relationship for 13 years with men who had chronic diseases. Data collection techniques in this study used interviews with two times of meetings with participants. The analysis technique used is an analysis of interpretative phenomenological analysis (IPA). The results of this study indicate that participants have different views about commitment. During the dating relationship, participants also face a variety of challenges that affect her commitment. The factors that strengthen the pairing commitment obtained through this study also vary.
\end{abstract}

Key words: dating commitment, female adult, chronic disease 
INSAN Jurnal Psikologi dan Kesehatan Mental, 2020, Vol. 5(1), 49-60, doi: 10.20473/jpkm.v5i12020.49-60

Dikirimkan: 13 Desember 2019 Diterima: 1 Mei 2020 Diterbitkan: 26 Juni 2020

Editor: Rizqy Amelia Zein

*Alamat korespondensi: Kampus B Unair, Jalan Airlangga 4-6 Surabaya, Jawa Timur 60286.

Pos-el: idaayu.kusumaastuti@gmail.com

Naskah ini merupakan naskah dengan akses terbuka dibawah ketentuan the Creative Common Attribution License (http://creativecommons.org/licenses/by/4.0), sehingga penggunaan, distribusi, reproduksi dalam media apapun atas artikel ini tidak dibatasi, selama sumber aslinya disitir dengan baik.

\section{P E N D A H U L U A N}

Pada masa dewasa awal, individu berada dalam tahap keenam perkembangan psikososial Erikson dimana konflik antara intimacy versus isolation menjadi persoalan utama. Menurut Erikson, individu yang memasuki masa dewasa awal dituntut untuk membangun relasi dan saling berkomitmen atau menghadapi rasa pengasingan diri dan keterpakuan pada diri sendiri (self-absorption). Jika seseorang gagal mengembangkan hubungan intim di awal masa dewasa, maka hal ini akan menyebabkan isolasi yang didefinisikan sebagai ketidakmampuan diri untuk mengembangkan hubungan yang bermakna dengan orang lain dan hal tersebut dapat membahayakan kepribadian seseorang (Santrock, 2010).

Relasi sosial yang terjalin pada masa ini memiliki tahap yang berbeda-beda. Mulai dari sekadar berteman, hingga akhirnya bersahabat. Persahabatan antar jenis kelamin melalui interaksi dan aktivitas bersama tidak menutup kemungkinan untuk berlanjut menjadi relasi yang lebih intim serta melibatkan komitmen untuk melanjutkan hubungan ke tahap yang lebih serius misalnya berpacaran (Papalia, Olds, \& Feldman, 2008). Paul dan White (dalam Santrock 2010) menyatakan bahwa menjalin hubungan pacaran dapat memberikan kesempatan bagi individu untuk belajar mengenai keterbukaan, umpan balik, serta belajar cara-cara untuk menyelesaikan konflik.

Menurut Taylor, Peplau, \& Sears (2009), usaha dalam pencarian teman hidup adalah usaha yang memerlukan banyak pertimbangan dan tidak jarang dapat menghabiskan waktu yang lama dalam prosesnya. Peran kesamaan sikap dan pandangan dalam kehidupan memainkan peran dalam pertimbangan pemilihan pasangan. Menurut Olson dan DeFrain (2003), individu juga memiliki kecenderungan memilih pasangan yang menarik secara fisik. Hal ini didasarkan pada hasil penelitian oleh Margolin dan White (dalam Olson dan DeFrain, 2003) yang menunjukkan bahwa terdapat beberapa pasangan yang mengalami permasalahan seksual dalam kehidupan pernikahannya ketika individu melanjutkan hubungan dengan pasangan yang dianggap tidak menarik secara fisik selama proses menjalin hubungan berpacaran.

Pada kenyataannya, tidak semua perempuan menjalani hubungan dengan laki-laki yang menarik atau sehat secara fisik. Wawancara awal yang dilakukan dengan partisipan penelitian menghasilkan data yang berbeda dengan teori maupun penelitian yang telah dilakukan sebelumnya. Partisipan penelitian yang berinisial E merupakan seorang wanita dewasa awal yang saat ini berusia 31 tahun. Saat ini, E memiliki pacar yang mengidap penyakit kronis, yaitu hipertensi, hipospadia, dan gagal ginjal. Pasangan E pernah menjalani prosedur cuci darah sebanyak 3 kali dalam seminggu selama 4 bulan. Kondisi tersebut diakibatkan oleh hipertensi dan terjadinya kesalahan pemberian obat hipospadia oleh dokter yang akhirnya menyebabkan masalah pada ginjal. Salah satu ginjal pacar E sudah tidak berfungsi, dan ginjal satunya hanya berfungsi $25 \%$. Saat ini, pasangan E masih perlu mengonsumsi obat dengan dosis yang lebih tinggi. Konsumsi obat tersebut memiliki efek samping pada telinga kanan pasangan E yang

INSAN Jurnal Psikologi dan Kesehatan Mental

Tahun 2020, Vol. 5(1), 49-60

doi: 10.20473/jpkm.v5i12020.49-60 
kini tidak berfungsi. Pertimbangan dalam meneruskan hubungan akan menjadi semakin kompleks ketika sumber permasalahan dalam suatu hubungan adalah karena pasangan mengalami sakit (Dharmawijati, 2016). Kemungkinan kehadiran pria lain yang lebih menarik secara fisik dan mapan secara ekonomi ketika wanita yang bersangkutan menjalani hubungan dengan pasangannya juga dapat menjadi tantangan tersendiri. Hal ini terjadi mengingat ada kecenderungan individu untuk memilih pasangan yang memiliki daya tarik dan kondisi fisik serta ekonomi yang baik (Olson \& DeFrain, 2003). Permasalahan yang dialami oleh E sangat kompleks, karena terkait dengan penyakit kronis yang diidap oleh pasangannya. Namun hingga manuskrip ini selesai, E mampu mempertahankan hubungan dengan pacarnya selama hampir 13 tahun dan mampu mempertahankan hubungan jarak jauh selama 4 tahun. E juga menyatakan bahwa ia akan tetap meneruskan hubungannya dengan pacarnya saat ini terlepas kondisi kesehatan pasangannya.

Idealnya, pada masa dewasa awal, terutama ketika sudah memasuki usia 30 tahun-an, seorang wanita sudah melanjutkan hubungan ke jenjang pernikahan dengan pasangan yang dianggap ideal untuk dirinya. Individu akan memiliki kecenderungan untuk memiliki pasangan yang mampu memberikan kesejahteraan baik secara biologis, psikologis, dan ekonomi; serta akan melanjutkan hubungan dengan pasangan yang memiliki banyak kesamaan dengan dirinya (Olson \& DeFrain, 2003). Pada kenyataannya, kondisi yang dialami partisipan tidak sesuai dengan kondisi yang ideal. Namun demikian, partisipan tetap mampu mempertahankan hubungan dengan pasangannya saat ini.

Pertanyaan yang muncul kemudian adalah bagaimana E dapat mempertahankan hubungan berpasangan dengan laki-laki yang memiliki penyakit kronis tersebut? Sampai di sini, tampak bahwa komitmen merupakan salah satu hal terpenting untuk mempertahankan hubungan yang dijalani. Hal ini didukung oleh pernyataan Rusbult (dalam Dharmawijati, 2016) bahwa ketika salah satu atau kedua pasangan tidak puas, tergoda oleh pilihan yang memikat, atau mengalami situasi yang mengancam suatu hubungan, hal ini dapat memperlemah komitmen pasangan sehingga dapat memengaruhi keputusan mereka. Namun, ketika pasangan merasa bahagia atau puas dengan hubungan yang dijalani, maka komitmen pasangan meningkat dan hubungan mereka akan tetap bertahan.

\section{Komitmen}

Komitmen atau keterikatan menunjuk pada segala kekuatan baik positif maupun negatif yang berfungsi untuk mempertahankan individu dalam suatu hubungan. Orang yang merasa terikat pada suatu hubungan dengan orang lain akan senantiasa berada bersama-sama dengan orang itu dalam suka maupun duka (Sears, Freedman, \& Peplau, 2009). Komitmen juga didefinisikan sebagai keputusan individu yang dibuat secara sadar untuk terikat kepada seseorang sepanjang waktu. Sternberg mengonsepkan komitmen sebagai salah satu komponen dari dari cinta. Lebih lanjut, ahli psikologi lain mendefinisikan komitmen sebagai sesuatu yang terpisah namun merupakan construct yang tumpang tindih (Lehmiller, 2014).

Berdasarkan perspektif model investasi yang dikemukakan oleh Agnew, Martz dan Rusbult (dalam Taylor, Peplau, \& Strears, 2009; Lehmiller, 2014) terdapat tiga faktor yang memengaruhi komitmen yaitu;

1) Kepuasan, menunjuk pada evaluasi subjektif individu terhadap hubungannya. Individu akan membandingkan hasil dari hubungannya apakah lebih baik atau lebih buruk dari hubungan sebelumnya atau apakah hasil tersebut juga didapatkan oleh orang lain dari hubungannya.

2) Ketersediaan alternatif, menunjuk pada persepsi mengenai bagaimana semua keinginan individu lain digabungkan ketika berkencan. Individu membandingkan hasil dari hubungannya saat ini dan berpikir akan mendapatkan hasil yang lebih baik dari orang lain. 
3) Investasi dapat berupa benda yang terlihat seperti objek materi, uang dan lain-lain. Investasi juga dapat berbentuk benda yang tidak terlihat seperti memori yang dibagikan, waktu, dan usaha.

\section{Dewasa Awal}

Istilah adult atau dewasa berasal dari kata kerja latin yang berarti tumbuh menjadi dewasa. Oleh karena itu, orang dewasa adalah seseorang yang telah menyelesaikan pertumbuhannya dan siap menerima kedudukannya di dalam masyarakat bersama dengan orang dewasa lainnya. Dewasa awal adalah masa peralihan dari masa remaja. Hurlock (1986) mengatakan bahwa dewasa awal dimulai pada usia 18 tahun sampai kira-kira usia 40 tahun. Secara umum, mereka yang tergolong dewasa awal ialah mereka yang berusia 20-40 tahun.

Santrock (2010) mengatakan masa dewasa awal adalah masa untuk bekerja dan menjalin hubungan dengan lawan jenis namun terkadang menyisakan sedikit waktu untuk hal lainnya. Kenniston (dalam Santrock, 2010) mengemukakan masa muda (youth) adalah periode kesementaraan ekonomi dan pribadi, dan perjuangan antara ketertarikan pada kemandirian dan keterlibatan secara sosial. Periode masa muda rata-rata terjadi 2 sampai 8 tahun, tetapi dapat juga lebih lama. Dua kriteria yang diajukan untuk menunjukkan akhir masa muda dan permulaan dari masa dewasa awal adalah kemandirian ekonomi dan kemandirian dalam membuat keputusan. Mungkin yang paling luas diakui sebagai tanda memasuki masa dewasa adalah ketika seseorang mendapatkan pekerjaan penuh waktu yang kurang lebih tetap (Santrock, 2010).

\section{Penyakit Kronis}

Penyakit kronis merupakan jenis penyakit degeneratif yang berkembang atau bertahan dalam jangka waktu yang sangat lama, yakni lebih dari enam bulan. Orang yang menderita penyakit kronis cenderung memiliki tingkat kecemasan yang tinggi dan cenderung mengembangkan perasaan hopelessness dan helplessness karena berbagai macam pengobatan tidak dapat membantunya sembuh dari penyakit kronis (Sarafino, 2006).

Penyakit kronis dapat diderita oleh semua kelompok usia, tingkat sosial ekonomi, dan budaya. Penyakit kronis cenderung menyebabkan kerusakan yang bersifat permanen yang memperlihatkan adanya penurunan atau menghilangnya suatu kemampuan untuk menjalankan berbagai fungsi, terutama muskuloskletal dan organ-organ pengindraan. Ada banyak faktor yang menyebabkan penyakit kronis dapat menjadi masalah kesehatan yang banyak ditemukan hampir di seluruh negara, di antaranya kemajuan dalam bidang kedokteran modern yang telah mengarah pada menurunnya angka kematian dari penyakit infeksi dan kondisi serius lainnya, nutrisi yang membaik dan peraturan yang mengatur keselamatan di tempat kerja yang telah memungkinkan orang hidup lebih lama, dan gaya hidup yang berkaitan dengan masyarakat modern yang telah meningkatkan insiden penyakit kronis (Smeltzer \& Bare, 2010).

Berdasarkan pemaparan di atas, tujuan penelitian ini adalah untuk mengetahui pengalaman mempertahankan komitmen pada perempuan dewasa awal yang menjalani perempuan dewasa awal yang menjalani hubungan dengan pria yang mengalami penyakit kronis. Grand tour question pada penelitian ini adalah bagaimana pengalaman mempertahankan komitmen pada perempuan dewasa awal yang menjalani hubungan dengan pria yang mengalami penyakit kronis? Untuk mendukung pertanyaan penelitian ini, dirumuskan 3 buah sub questions, yaitu;

1) Apa makna komitmen menurut pandangan partisipan? 
2) Apa saja faktor-faktor yang memperkuat hubungan berpasangan yang dijalani oleh partisipan?

3) Apa saja tantangan yang dihadapi ketika partisipan mempertahankan hubungan berpasangan?

\section{E T O D E}

\section{Desain Penelitian}

Penelitian ini menggunakan pendekatan kualitatif, dengan tipe penelitian fenomenologi. Menurut Langdridge (2007) pendekatan fenomenologi merupakan tradisi penelitian kualitatif yang berakar pada filosofi dan psikologi, serta fokus pada pengalaman hidup manusia (sosiologi). Penelitian ini akan berdiskusi tentang suatu objek kajian dengan memahami inti pengalaman dari suatu fenomena. Peneliti akan mengkaji secara mendalam isu sentral dari struktur utama suatu objek kajian dan selalu bertanya mengenai apa pengalaman utama yang akan dijelaskan informan tentang partisipan kajian penelitian.

\section{Partisipan}

Unit analisis dalam penelitian ini adalah pengalaman mempertahankan komitmen berpasangan pada perempuan dewasa awal yang menjalani hubungan dengan laki-laki yang memiliki penyakit kronis. Penelitian ini fokus dalam mengkaji gambaran komitmen individu perempuan yang memasuki masa dewasa awal (berusia 31 tahun) yang sudah berpacaran selama 13 tahun dengan seorang pria yang memiliki penyakit kronis. Di balik semua kondisi yang dialami, partisipan tetap bertahan dalam mempertahankan hubungan. Sebelum proses pengambilan data, peneliti terlebih dahulu meminta kesediaan partisipan dalam mengisi kuesioner penelitian secara lisan.

\section{Teknik Penggalian Data}

Pengumpulan data dalam penelitian ini menggunakan metode wawancara mendalam. Proses wawancara ini dilengkapi dengan pedoman wawancara yang digunakan untuk mengingatkan kembali peneliti mengenai aspek-aspek yang dibahas sekaligus menjadi panduan apakah aspek-aspek yang relevan telah ditanyakan atau dibahas (Patton, dalam Poerwandari, 2011).

\section{Analisis Data}

Setelah mendapatkan data, proses selanjutnya adalah mengodekan dan analisis. Teknik analisis data yang digunakan penulis adalah Interpretative Phenomenological Analysis (IPA). Fokus studi IPA adalah pada bagaimana seseorang merasakan suatu pengalaman. Pada dasarnya, analis berkepentingan dengan memahami dunia peserta. Oleh karena itu, penelitian ini menghabiskan banyak waktu bekerja melalui transkrip (dan mendengarkan rekaman) untuk mengidentifikasi tema-tema utama.

Untuk mempertahankan kredibilitas data, peneliti menggunakan metode member checking, yaitu melakukan konfirmasi terhadap partisipan terkait hasil analisis yang telah dibuat. Tujuannya adalah untuk menjaga agar hasil yang didapatkan sesuai dengan pengalaman yang dirasakan oleh partisipan.

\section{HAS IL PENELIT IAN}

E merupakan seorang wanita berusia 31 tahun yang saat ini sedang bekerja sebagai dosen magang di salah satu Perguruan Tinggi di Surabaya. Partisipan lahir dan dibesarkan oleh keluarganya di Medan. Partisipan merupakan anak pertama dari tiga bersaudara. E tinggal bersama dengan kedua orang tua

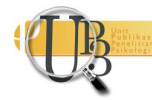


dan tiga saudara lainnya. Namun saat ini, E tinggal terpisah dengan keluarganya dikarenakan pekerjaannya sebagai dosen magang. Sejak kecil, E merupakan seorang anak berprestasi secara akademik maupun non-akademik sehingga orang tua partisipan menaruh harapan yang cukup besar kepada E. Meskipun menjadi anak kebanggaan di keluarganya, hal itu tidak serta merta membuat E mendapatkan perhatian dan kasih sayang seperti yang E harapkan. E mengaku bahwa keluarganya termasuk keluarga yang kurang harmonis. Pola asuh ayah E termasuk dalam pola asuh yang otoriter. E kemudian menjadi anak yang pendiam karena takut disalahkan oleh ayahnya. Oleh karena itu, E tidak pernah terbuka dan menceritakan permasalahan kepada keluarganya. E dan keluarganya juga memang tidak terbiasa untuk saling bercerita tentang kehidupan sehari-hari atau hanya sekadar untuk berkumpul makan bersama. Menurut E, ketidakharmonisan keluarganya bisa jadi disebabkan oleh ikatan ayah dan ibunya yang tidak begitu kuat karena orang tuanya menikah melalui perjodohan.

Saat E menjalani perkuliahan di salah satu perguran tinggi di Medan. Partisipan memiliki sahabatsahabat yang mayoritas berjenis kelamin laki-laki. Partisipan mengaku lebih menyukai bertukar cerita dan beraktivitas dengan teman laki-lakinya karena dianggap lebih bisa berpikir realistis dan menyenangkan. Namun seiring dengan berjalannya waktu, salah satu sahabatnya menjalin hubungan romantis dengannya. E bertemu dengan pasangannya di sekitar pertengahan September tahun 2005, dan mulai berpacaran pada 5 Desember 2005.

Selama menjalani hubungan, E mengaku pasangannya sangat memahami dan mampu menjadi sosok yang bisa selalu ada disaat E butuhkan. E juga mengatakan bahwa dirinya bisa menjadi seorang yang apa adanya apabila dengan pasangannya. Walaupun E sudah menunjukkan perilaku-perilaku yang tidak menyenangkan kepada pasangan seperti mudah marah atau banyak menuntut sesuatu, pasangan $\mathrm{E}$ tetap mampu menjadi sosok yang sabar dan memahami dirinya dengan baik. Meskipun hubungan $\mathrm{E}$ dengan pasangannya tampak cukup harmonis, namun sejak awal, sebenarnya E dan pasangannya tidak mendapatkan restu dari orang tua kedua belah pihak karena perbedaan agama. Hanya saja, mereka tetap melanjutkan hubungan mereka walaupun tidak direstui orang tua karena sudah merasa cocok satu sama lain.

Pada tahun 2007, terdapat suatu kejadian yang cukup mengejutkan E karena pasangan E tiba-tiba jatuh sakit hingga harus melakukan cuci darah sebanyak 3 kali seminggu selama 4 bulan. Saat itu, pasangan E diketahui mengalami hipertensi dan terjadi kesalahan pemberian obat oleh dokter yang akhirnya menyebabkan masalah pada ginjalnya. Setelah itu, pada tahun 2008, E mengetahui bahwa pasangannya mengalami hipospadia. E awalnya memang mencurigai perilaku buang air kecil pasangannya yang tidak seperti kebanyakan laki-laki pada umumnya. Saat itulah pasangan E mengatakan bahwa dirinya mengalami penyakit hipospadia.

Seiring berjalannya waktu, kondisi pasangan E tidak menunjukkan prognosis yang positif. Saat ini, salah satu ginjal pasangan E sudah tidak berfungsi, dan ginjal yang lainnya hanya berfungsi $25 \%$. Pasangan E sudah berhenti melakukan cuci darah tetapi masih perlu mengonsumsi beberapa obat secara rutin dan menjaga pola makan. Pasangan E meminum obat ginjal dengan dosis lebih tinggi sehingga obat tersebut memberikan efek samping yaitu membuat telinga kanannya tidak berfungsi. Pasangan $\mathrm{E}$ juga memiliki beberapa komplikasi lain seperti hipertensi, kolesterol tinggi, dan impotensi yang disebabkan oleh penyakit hipospadia.

E memiliki kontribusi yang cukup besar untuk membantu perawatan medis pasangannya. E sering membantu pasangannya ketika harus melakukan kontrol maupun operasi di rumah sakit. Pasangan E juga selalu meminta agar E yang bisa menemani dirinya untuk melewati segala proses tersebut. Namun selama menjalani hal tersebut, E tetap menerima penolakan dari keluarga pasangan. Pada saat E merawat pasangannya di rumah sakit, keluarga pasangan tidak menganggap kehadiran E. Keluarga pasangan $\mathrm{E}$ sangat tidak menyukai hubungan $\mathrm{E}$ dengan pasangan, terutama adik perempuan pasangan

INSAN Jurnal Psikologi dan Kesehatan Mental

Tahun 2020, Vol. 5(1), 49-60

doi: 10.20473/jpkm.v5i12020.49-60 
E. Adik pasangan $\mathrm{E}$ itu bahkan pernah memaki $\mathrm{E}$ di depan umum dan meminta agar $\mathrm{E}$ tidak menjenguk kakaknya lagi. Disisi lain, orang tua E meminta agar E memutuskan hubungan dengan pasangannya karena berbagai macam faktor yang ada, akan tetapi E mengabaikan permintaan orang tuanya.

Tantangan lainnya yang dihadapi E selama menjalin hubungan dengan pasangannya tidak hanya sampai di sana saja. Berdasarkan hasil penelitian yang telah dilakukan, tantangan-tantangan tersebut antara lain tantangan yang bersifat internal dan eksternal. Tantangan internal adalah tantangan yang berasal dari dalam diri E seperti adanya kebutuhan untuk bersama dengan orang lain. E mengaku sebelumnya pernah mencoba menjalani hubungan dengan laki-laki lain namun pada akhirnya $\mathrm{E}$ tidak mampu berpaling karena sampai saat ini belum bisa menemukan orang lain yang lebih baik dibandingkan pasangannya. Respon dari pasangan $\mathrm{E}$ juga tetap sabar dan membebaskan keputusan $\mathrm{E}$ apabila memang ingin berhubungan dengan laki-laki lain. Hal ini membuat $E$ menjadi semakin yakin untuk mempertahankan hubungannya dengan pasangannya.

Meskipun tantangan yang dihadapi E dan pasangannya tergolong cukup rumit dan kompleks, hubungan selama 13 tahun yang mereka jalani tetap bertahan tentunya disebabkan oleh faktor-faktor tertentu. Hasil penelitian kemudian mengungkap bahwa ditemukan faktor-faktor internal dan juga faktor-faktor eksternal yang berkontribusi pada bertahannya hubungan E dengan pasangan. Salah satu faktor internal tersebut adalah kesetiaan, kejujuran, dan kepercayaan E terhadap pasangan. E mengungkapkan bahwa dirinya sudah menjadi bagian dari diri pasangannya sehingga E merasa tidak ada lagi yang perlu ditutup-tutupi kepada pasangannya. Keadaan ini tentunya membuat E merasa nyaman dengan hubungan yang dirinya jalani. E juga mampu beradaptasi dengan kondisi pasangannya. Hal ini terlihat dari ketekunan E untuk merawat pasangannya ketika sedang melakukan rawat jalan atau pengobatan terkait penyakitnya. E justru merasa khawatir apabila E tidak diberikan kesempatan untuk membantu pasangannya secara langsung ketika menjalani pengobatan di rumah sakit. E kemudian beradaptasi dan merasa senang dengan aktivitas tersebut karena hal itu mampu mengurangi rasa khawatirnya terhadap pasangannya.

Faktor eksternal adalah faktor-faktor yang memperkuat hubungan dari luar diri E. Adapun faktor-faktor eksternal yang memperkuat hubungan E salah satunya adalah perilaku pasangannya yang sesuai dengan harapan E. Menurut E, pasangannya memahami cara menempatkan diri ketika E sedang berada dalam kondisi-kondisi tertentu. Pasangannya sadar kapan E harus didekati atau diberi waktu untuk menyelesaikan masalahnya sendiri tanpa harus E mengatakannya. Komunikasi juga menjadi poin penting yang menguatkan hubungan E dengan pasangannya. E mengaku bahwa dalam kondisi sedang dalam perawatan di rumah sakit sekali-pun, pasangannya akan tetap menghubungi E untuk memberikan kabar. Ketika menjalani hubungan jarak jauh, pasangan E juga memiliki jadwal untuk menelepon E sehingga perilaku pasangan E selalu konsisten dan menepati janji.

Berdasarkan hasil pemaparan tersebut, E kemudian memiliki pemaknaan akan komitmen hubungan yang mungkin berbeda dari masyarakat pada umumnya. E menganggap bahwa ikatan pernikahan tidak terlalu penting, namun yang terpenting adalah kehadiran pasangan. Jika pada akhirnya hubungan berakhir dengan pernikahan, komitmen dalam menjalani pernikahan menurut E adalah hanya antara dua individu bukan kedua belah pihak keluarga sehingga restu dari keluarga bukanlah sesuatu hal yang penting atau perlu diprioritaskan. 
Tabel 1. Tantangan dalam menjalani hubungan

\begin{tabular}{ll}
\hline \multicolumn{1}{c}{ Tnternal } & \multicolumn{1}{c}{ Eksternal } \\
\hline Perasaan tidak nyaman dengan orang tua & Penolakan dari keluarga \\
Masalah dalam asertifitas & Perjodohan oleh orang tua \\
Adanya kebutuhan untuk bersama orang lain & Tidak mendapat restu orang tua dan \\
Pandangan terkait perilaku seksual & keluarga \\
dalam hubungan & Masalah Komunikasi \\
Emosi yang kurang stabil & Tekanan sosial \\
Perasaan jenuh terhadap pasangan & Kehadiran orang ketiga \\
Perasaan tidak nyaman dengan orang tua & \\
\hline
\end{tabular}

Tabel 2. Faktor yang Memperkuat Hubungan Kategori Internal

\section{Faktor yang Memperkuat Hubungan \\ Kategori Internal}

Loyalitas terhadap hubungan

Dukungan terhadap pasangan

Pandangan positif terhadap pasangan

Kehadiran satu sama lain

Penerimaan resiko dalam hubungan

Penerimaan kondisi pasangan

Rencana hubungan jangka panjang
Pandangan terhadap diri

Kesetiaan tehadap pasangan

Keyakinan terhadap Tuhan

Kejujuran dan kepercayaan pasangan

Beradaptasi dengan kondisi pasangan

Perlakuan istimewa terhadap pasangan

Tabel 3. Faktor yang Memperkuat Hubungan Kategori Eksternal

\begin{tabular}{ll}
\hline & $\begin{array}{c}\text { Faktor yang Memperkuat Hubungan } \\
\text { Kategori Eksternal }\end{array}$ \\
\hline Konsistensi dalam komunikasi & Cara menjaga intimasi \\
Konsistensi dalam menepati janji & Kejujuran pasangan \\
Dukungan pasangan & Kepercayaan pasangan \\
Kesetiaan terhadap pasangan & Kesesuaian dalam pemikiran \\
Prinsip pasangan dalam mempertahankan hubungan & Kesesuaian pengalaman hidup \\
Loyalitas pasangan dalam bentuk materi & Perlakuan istimewa terhadap pasangan \\
Kesabaran pasangan & Respon lingkungan terhadap hubungan \\
Pasangan mampu memahami kondisi E & Perhatian pasangan \\
& Ketiadaan alternatif pasangan \\
\hline
\end{tabular}


Tabel 4. Makna Komitmen

\section{Makna Komitmen}

Komitmen dalam menjalani hubungan terdiri dari dua individu bukan dua keluarga

Komitmen dalam menjalani hubungan merupakan perasaan sebagai suatu kesatuan dengan pasangan

Komitmen adalah keyakinan yang utuh terhadap pasangan

Makna komitmen dalam menjalin hubungan adalah adanya kenyamanan, keberadaan, kehadiran, Kedalaman emosi dan saling menjaga secara fisik dan mental.

\section{I S K U S I}

Permasalahan yang dialami oleh E sangat kompleks karena terkait dengan penyakit kronis yang dialami oleh pacarnya, serta tidak direstuinya hubungan yang dijalani oleh kedua pihak keluarga. Menurut Rusbult (dalam Dharmawijati, 2016) ketika salah satu atau kedua pasangan dihadapkan pada kondisi yang menyebabkan ketidakpuasan atau mengalami situasi yang mengancam suatu hubungan, maka hal ini dapat memperlemah komitmen pasangan. Tetapi hal yang berbeda dengan apa yang dialami pada E. Sampai manuskrip ini selesai, E mampu mempertahankan hubungannya dengan pasangannya selama hampir 13 tahun. Selama perjalanan hubungan mereka pun sempat terjadi hubungan jarak jauh (long distance relationship) selama 4 tahun karena penempatan kerja pasangan $\mathrm{E}$ yang berbeda dengan $\mathrm{E}$, namun mereka masih memutuskan untuk tetap bertahan. E juga menyatakan bahwa dirinya akan tetap meneruskan hubungannya dengan pasangannya saat ini, meskipun pasangan E mengalami sakit dan hubungannya tidak direstui oleh keluarga.

Di balik banyaknya tantangan yang dihadapi E, terdapat beberapa faktor yang menyebabkan E masih mempertahankan hubungan dengan pasangannya. Menurut Finkell, Rusbult, Kumashiro, \& Hannon (2002) komitmen melibatkan peningkatan kepentingan interpersonal atau kelekatan psikologis. Komponen ini didasarkan pada persepsi bahwa kesejahteraan diri sendiri dan kesejahteraan pasangan saling terkait. Komitmen dapat menghasilkan orientasi komunal termasuk kecenderungan untuk merespon kebutuhan pasangan tanpa syarat. Individu yang berkomitmen dapat mengerahkan usaha tanpa menghitung apa yang diterima sebagai imbalan; tanpa memperhitungkan apakah kebaikan yang dilakukan akan dibalas atau tidak. Hal ini juga terjadi pada E yaitu adanya loyalitas pasangan untuk berusaha membahagiakan E. Loyalitas pasangan ini berbentuk kesetiaan, kesabaran, serta perilaku memaafkan yang pasangan E lakukan kepada E. Seperti yang diketahui sebelumnya E merupakan sosok individu yang memiliki kontrol emosi yang kurang baik namun E merasa sampai saat ini pasangan E memiliki sifat positif untuk bisa memahami dirinya seperti yang E harapkan. Loyalitas pasangan yang diberikan ini membuat $\mathrm{E}$ merasa yakin belum bisa menemukan pria lain yang lebih baik.

Meskipun E sering mendekati laki-laki lain, pasangan E memperlakukannya dengan sangat sabar, berbeda dengan perlakuan pasangan E ke orang lain. Di sisi lain, E tidak pernah bepikir untuk menjalin hubungan dengan pria lain, meskipun ada yang mendekati E. Hal ini karena E tidak bisa merasa nyaman sepenuhnya dengan pria yang mendekatinya. E hanya merasa nyaman bersama pasangannya karena pasangan E paham bagaimana memperlakukan E sesuai keinginannya. E merasa pasangannya memiliki pengalaman hidup yang sama seperti kesamaan makanan yang tidak disukai maupun pengalaman pernah keluar masuk rumah sakit. Adanya kesamaan sifat dan pengalaman yang dirasakan oleh kedua pasangan merupakan salah satu faktor yang dapat memperkuat komitmen dalam suatu hubungan karena hal ini dapat mempermudah individu untuk mengerti satu sama lain (Olson \& DeFrain, 2003).

Bagi kebanyakan orang, merawat orang dengan penyakit kronis membutuhkan tenaga dan waktu. Periode hemodialisis dan rutinitas pengobatan yang menjadi gaya hidup pada pasien dengan gagal ginjal (penyakit kronis) dapat menciptakan konflik, frustasi, marah dan depresi. Hal ini menyulitkan pasien,

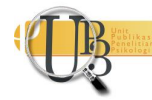


pasangan, dan keluarga untuk mengekspresikan perasaan (Daugirdas, dalam Pratiwi, 2008) dan menyebabkan berbagai macam konflik. Namun, penelitian ini menemukan bahwa E tidak menganggap kondisi pasangannya adalah sebuah tantangan atau faktor yang memperlemah hubungannya. E mampu bertahan dengan pasangan yang rutin menjalani pengobatan akibat penyakit kronis yang dimiliki karena dalam riwayat 13 tahun berpacaran, E mulai memahami dan terbiasa untuk merawat pasangannya. Bahkan E merasa khawatir ketika tidak merawat pasanganya secara langsung. Seiring berjalannya waktu, E akhirnya beradaptasi dengan kondisi pasangannya dan merasa senang untuk merawat pasangannya.

Menurut Olson dan DeFrain (2003), komitmen merupakan keterikatan kognitif dengan orang lain. Komitmen berkembang dari waktu ke waktu, mulai perlahan dan meningkat pada tingkat yang lebih cepat jika hubungannya positif. Jika hubungan gagal, komitmen menghilang. Sebagian besar individu menyatakan berkomitmen ketika mereka melanjutkan hubungan mereka ke tahap yang lebih maju (dari berkencan ke pertunangan, dari pertunangan ke pernikahan), ketika mereka setia, atau ketika mereka tetap berada dalam hubungan selama masa-masa sulit (Olson \& DeFrain 2003). Orang yang merasa terikat pada suatu hubungan dengan orang lain akan senantiasa berada bersama-sama dengan orang itu dalam suka maupun duka (Sears, Freedman, \& Peplau, 2009). Dalam penelitian ini, bentuk komitmen E adalah tetap mempertahankan hubungan selama masa-masa sulit. E tetap bisa mempertahankan komitmen dan menjalin hubungan dengan pasangan yang memiliki penyakit kronis, mengalami permasalahan dengan restu orang tua, dan kehadiran orang ketiga dalam hubungan. Menurut E, pernikahan tidak terlalu penting dalam suatu komitmen, karena yang terpenting adalah kehadiran pasangan.

Menurut Olson dan DeFrain (2003), terdapat beberapa faktor yang berperan dalam mempertahankan komitmen dan intimasi, antara lain kemampuan berkomunikasi, kemampuan pemecahan masalah, hubungan seksual, fleksibilitas pasangan, kedekatan pasangan, dan sifat-sifat yang dimiliki oleh pasangan. Namun, terdapat temuan yang berbeda dalam penelitian ini karena E tidak menganggap hubungan seksual dan keinginan untuk menikah menjadi faktor yang dapat mempertahankan komitmen. E lebih menekankan bahwa kehadiran pasangan dan sifat pasangan yang sesuai dengan kriteria merupakan sumber kekuatan untuk mempertahankan komitmen.

\section{S I M P U L A N}

Dalam menjalin hubungan dengan lelaki yang memiliki penyakit kronis, terdapat beberapa pengalaman yang terungkap. Adapun dalam menjalani hubungan, terdapat 6 tantangan yang bersifat internal dan 6 tantangan yang bersifat eksternal. Tantangan internal adalah tantangan yang berasal dari dalam diri $\mathrm{E}$ antara lain perasaan tidak nyaman dengan orang tua, adanya kebutuhan untuk bersama dengan orang lain, emosi yang kurang stabil, masalah dalam asertifitas, pandangan terkait perilaku seksual dalam hubungan, dan perasaan jenuh terhadap pasangan. Dalam menjalani hubungan terdapat pula tantangan yang bersifat eksternal yang berasal dari luar diri E antara lain adanya penolakan dari keluarga, tidak mendapat restu orang tua dan keluarga, adanya tekanan sosial, adanya perjodohan oleh orang tua, masalah dalam komunikasi, serta hadirnya orang ketiga.

Terdapat faktor-faktor yang memperkuat hubungan E dengan pasangan sehingga E tetap dapat mempertahankan hubungan selama lebih dari 13 tahun. Adapun faktor-faktor tersebut terdiri dari faktor internal dan faktor internal. Faktor internal adalah faktor-faktor yang memperkuat hubungan $\mathrm{E}$ yang berasal dari diri pribadi E antara lain loyalitas terhadap hubungan, dukungan E terhadap pasangan, pandangan positif $\mathrm{E}$ terhadap pasangan, kehadiran satu sama lain, penerimaan E terhadap resiko dalam hubungan, penerimaan E terhadap kondisi pasangan, adanya rencana jangka panjang yang dimiliki E. Adapun faktor internal lainnya antara lain pandangan E terhadap diri E, kesetiaan E terhadap pasangan,

INSAN Jurnal Psikologi dan Kesehatan Mental

Tahun 2020, Vol. 5(1), 49-60

doi: 10.20473/jpkm.v5i12020.49-60

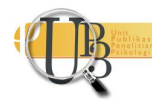


keyakinan E terhadap Tuhan, kejujuran, dan kepercayaan E terhadap pasangan, E yang beradaptasi dengan kondisi pasangan, perlakuan istimewa E kepada pasangan, terciptanya makna pernikahan yang E miliki.

Faktor eksternal adalah faktor-faktor yang memperkuat hubungan dari luar diri E. Adapun faktor-faktor eksternal yang memperkuat hubungan E dengan pasangan antara lain adanya konsistensi dalam komunikasi, konsistensi dalam menepati janji, dukungan pasangan, kesetiaan terhadap pasangan, prinsip pasangan dalam mempertahankan hubungan, loyalitas pasangan dalam bentuk materi, makna pernikahan oleh pasangan, kesabaran pasangan, pasangan mampu memahami kondisi E, pasangan memiliki cara dalam menjaga intimasi, kejujuran pasangan, kepercayaan pasangan, kesesuaian pasangan dalam pemikiran, serta kesesuaian pasangan dalam pengalaman hidup dengan E. Adapun faktor eksternal lainnya antara lain perlakuan istimewa yang pasangan berikan, respon lingkungan terhadap hubungan, perhatian pasangan dan ketiadaan alternatif pasangan.

Berdasarkan hasil penelitian terdapat 4 makna komitmen dalam menjalani hubungan yang terungkap dalam pengalaman $\mathrm{E}$ yang menjalin hubungan dengan laki-laki yang memiliki penyakit kronis antara lain komitmen dalam menjalani hubungan terdiri dari dua individu bukan dua keluarga, komitmen dalam menjalani hubungan merupakan perasaan sebagai suatu kesatuan dengan pasangan, komitmen adalah keyakinan yang utuh terhadap pasangan, makna komitmen dalam menjalin hubungan adalah adanya kenyamanan, keberadaan, kehadiran, kedalaman emosi dan saling menjaga secara fisik dan mental.

Adapun beberapa temuan tambahan yang turut memengaruhi hubungan E antara lain sifat E yang tertutup, pengalaman tidak menyenangkan yang dialami, hubungan yang tidak harmonis dengan saudara, hubungan yang tidak harmonis dengan orang tua, sifat individu yang menghindari konflik, pola asuh orang tua E yang otoriter, dan hubungan orantua yang tidak harmonis.

\section{U C A P A N T E R I M A K A S I H}

Penyusunan artikel penelitian ini tidak terlepas dari dukungan dan doa dari beberapa pihak. Kami sebagai tim penulis ingin mengucapkan terima kasih kepada Dr. Wiwin Hendriani, M.Sc., dan bapak Ilham Nur Alfian, M.Psi., Psikolog selaku dosen pengampu mata kuliah kualitatif pada program Magister Psikologi Profesi Fakultas Psikologi Universitas Airlangga yang telah membimbing kami dalam menyelesaikan penelitian ini. Penulis juga menyampaikan terimakasih kepada partisipan penelitian yang sudah bersedia meluangkan waktu sehingga penelitian ini dapat diselesaikan sesuai dengan tujuan dan harapan kami.

\section{DEKLARASI POTENSI TERJADINYAKONFLIK KEPENTINGAN}

Kami selaku tim penulis dengan ini mendeklarasikan bahwa artikel penelitian ini tidak memiliki konflik kepentingan dengan pihak manapun. Kami juga tidak menerima dana dari perusahaan atau organisasi manapun yang mungkin dapat mengambil keuntungan dari diterbitkannya naskah ini.

\section{P USTAKA ACUAN}

Dharmawijati, R. D. (2016) Komitmen dalam berpacaran jarak jauh pada dewasa awal. eJournal Psikologi, 4 (2), 237 - 248. 
Finkel, E.J., Rusbult, C.E., Kumashiro, M., Hannon, P. A. (2002). Dealing With Betrayal in Close Relathionship Does Commitment Promote Forgiveness. Journal of Personality and Social Psychology, 82 (6), 956-974. DOI: 10.1037//0022-3514.82.6.956

Hurlock, Elizabeth B. (1986). Developmental Psychology (3rd Ed.). New Delhi: McGraw Hill, Inc.

Langdridge, D. (2007). Phenomenology Psychology: Theory, Research and Method. Harlow: Pearson Prentice Hall.

Lehmiller, J. J. (2014). The Psychology of Human Sexuality. West Sussex, UK: John Wiley \& Sons, Ltd.

Olson, D.H. \&DeFrain, J. (2003). Marriages and families: Intimacy, diversity and strength (4th). United States: McGraw-Hill.

Papalia, D.E., Olds, S.W., \& Feldman, R.D. (2008). Human development (10th). New York: McGraw-Hill.

Poerwandari, E.K. (2011). Pendekatan Kualitatif untuk Penelitian Perilaku Manusia. Jakarta: LPSP3 Fakultas Psikologi Universitas Indonesia.

Pratiwi, S.H. (2008). Gambaran stresor dan mekanisme koping pasien hemodialisis di RSUD Sumedang tahun 2008. FIK- Universitas Padjajaran, Skripsi

Santrock, J. W. (2010). Child development (15th ed.) (M. Rachmawati \& A. Kuswanti, Trans.). Jakarta: Erlangga.

Sarafino, E. P. (2006). Health Psychology: Biopsychosocial Interactions. Fifth Edition. USA: John Wiley \& Sons.

Sears, David O., Freedman, J. L., Peplau, L.A. (2009). Psikologi Sosial. Jakarta: Kencana.

Smeltzer, S. C., \& Bare, B. G. (2010). Textbook of Medical-Surgical Nursing. Philadelphia: Lippincott Williams \& Wilkins.

Taylor, S. E., Peplau, L. A., \& David O. Sears. (2009). Psikologi sosial edisi kedua belas. Jakarta: Kencana Prenada Media Group. 